\title{
Promoting Local Wisdom in International Primary Curriculum Aims to Develop Learners' Problem Solving Skills
}

\author{
Agus Kristanto ${ }^{1}$, Suharno ${ }^{2}$, Gunarhadi ${ }^{3}$
}

\section{ARTICLE INFO}

\section{Article History:}

Received 03.01.2019

Received in revised form

Accepted 28.03.2019

Available online 01.07.2019

\begin{abstract}
Providing the best quality of education service must correlate to students' need in facing future challenges. This study aims to identify needs in integrating local wisdom to international curriculum and to define the effect of using International Primary Curriculum module, by introducing local wisdom, to develop students' problem solving skill. Research and Development method with ADDIE model is applied to produce module that answers the need. The participants include Grade 6 students of Primary Program Focus Independent School, Surakarta, Indonesia. The analysis stage provides data on learners' initial performance, school facilities and needs. The prototype produced at the design stage, with its product validation carried out by experts on the instructional media, the material for content eligibility, aspects of presentation feasibility and language, and experts' feedbacks are taken as standards to implement module in the class. Problem Based Learning in the IPC module provides data that students' mindset in digging information, developing ideas, planning, making decisions and conclusions undergo changes. This can be seen from the results of observation when students do exploring, thinking, planning, analyzing and synthesizing. However, students' ability in evaluating has not shown equal quality to other problem solving aspects. The percentage of activity in the module that emphasizes the initial phases of problem solving, i.e. problem identification, information gathering, developing ideas and planning can be potential causes for students to have less progress in this area. The increasing number of students qualifying the standard indicates that the use of module can promote better thinking skills.
\end{abstract}

C IJERE. All rights reserved

Keywords:

Local Wisdom, problem solving skill, module

\section{INTRODUCTION}

The globalization era and growth of technology have led to rapid changes in learning. Students are getting more familiar with the use of technology in learning than engaging in traditional learning approaches. Students' ways of thinking in processing information are also evolving. Raja (1991) states that science and technology are now established as forces of great power in the shaping of the futures. The developing countries face the challenge of creating for themselves pathways of learning which may lead to the mainstream of the knowledge revolution. Providing sufficient learning experience to develop new skills and competencies to face global competition is required to design in modern society.

Facilitating students with sufficient skills to survive in modern life must be taken as an important aspect in learning. The EFA Global Monitoring Report (UNESCO, 2012:14) identifies three skills that young people must possess, i.e. foundation, transferable, technical and vocational skills. Transferable skills include the ability to solve problems, the ability to communicate ideas and information effectively, creatively, show leadership and be able to innovate. Every individual needs these skills to adapt to different environments and create opportunities to promote.

Students' abilities in adapting to different environments can be promoted by providing real life experiences. Dewey (Mudjiman, 2011: 59) states that the learning process will only occur if students are faced with problems from real life to solve. In discussing and answering problems, students must be involved in real activities. Dewey argues that problem based learning (PBL) stimulates students to analyze problems, draw answers, search for data, analyze data and deduce answers to problems. In other words, this model basically trains problem solving skills through systematic steps. Problem solving skills become one of the basic skills that must be possessed by each individual. It uses a range of skills such as data handling, reading, modelling, logic and reasoning. 
The need to correlate learning to a real life situation is also aligned to the concept of international mindedness as promoted in the International Primary Curriculum (IPC). Students are motivated to learn more from their surrounding. IPC emphasizes the need of promoting such mindset in learning:

“... you are best positioned to help your children develop an international mindset. At the very least, this means helping children see how they can be proud of their own national heritage and culture and, at the same time, deeply respectful of the heritage and culture of others" (IPC Implementation File, 2016:5).

It describes the need of knowing students' own national heritage and culture to developing an international mindedness. The need of seeing the pride of national heritage and culture is an essential aspect to develop. Ardiansyah, Suharno \& Triyanto (2018) confirm that cultural heritage through learning is something that must be implemented including in the era of disruption. Appropriate techniques or strategies should be implemented by implementing learning to carry out educational functions in the inheriting of national culture. It is not just a teacher who has the obligation to perform a cultural inherent function in the implementation of learning but all the educational components that must work together to pass cultural through the implementation of learning. The UNESCO International Commission recommends four pillars of learning that students need to have to enter the $21^{\text {st }}$ century, as follows: Learning to Know, Learning to Do, Learning to Live Together, and Learning to Be (UNESCO, 1996). Learning to Be is the final of the three initial pillars. It describes the formation of human beings who are able to know themselves, human beings who have a steady and independent personality, intact humans who have emotional and intellectual stability, who can control themselves and who have empathy. Empathy becomes an important value to deliver. It correlates to the need of promoting local culture, e.g. Javanese's tepo sliro, in learning activities.

The modern era with the internet as a technological tool can truly change the "attitude of life" and "skills for life". The internet is an important tool for knowledge transfer, it makes people "smarter" and "more skilled" doing something, yet it does not simply make people "be wiser" (Harefa, 2000: 103). The internet can make the learning process much more enjoyable and much easier because of its various source of information. Data and knowledge can also be obtained quickly and at low cost. However, learning to be can only be done by engaging in real life. Satyananda, Sanjaya, Dwikanaya \& Nitbani (2013) state local wisdom as the community's wisdom or local genius deriving from the lofty value of cultural tradition in order to manage the community's social order or social life. Wisdom should also be understood in a broad sense, i.e. not only in the form of cultural norms and values, but also all elements of ideas including those that have implications for technology, handling health and aesthetics (Sedyawati, 2010: 382).

\section{Situation of the Problem}

The fact that many young people now forget local wisdom is one of the things that lies behind research in the field of education. Students tend to absorb the value of modern culture easier than local superiority. Fajarini (2014) states that local wisdom is decreasing due to human's action in fulfilling their needs. People do not take further thinking in keeping the importance of local culture to support their lives. Furthermore, Fajarini recommends the need of responding the growth of modern civilization by keeping local wisdom to be integrated in a real life situation. Ease of access to explore global information by using gadgets must be aligned to the awareness of knowing the development of information that occurs in the environment.

Designing activities that can attract students' willingness to explore local culture is a challenge to take. It can be developed more by going deeper in information process as one of the steps in promoting problem solving skills. Information process requires thinking skill. Finding the best ways to facilitate students' need is highly required. The use of technology to develop students' problem solving skill by promoting local wisdom is expected to show good results in responding to current situation.

\section{Aims of the Study}

The study aims to identify needs in integrating local wisdom to international curriculum and to define the effect of using IPC module, by introducing local wisdom, to develop students' problem solving skill. The IPC module is designed and developed based on the result of need, learner and curriculum analysis. Problem identification, information gathering, ideas sharing and planning, and analysis are then attached in the module 
in forms of activities by integrating values on local cultures. Important information about Surakarta, commonly known as Solo, i.e. its history, significant people, historical landmarks, transportation system and traditional markets, are taken as tools to trigger students' attention in identifying problems occured in the city. Students' knowledge about Solo is an aspect to improve at earlier activities. Problem identification occurs as a result of seeing how Solo City develops from time to time. Students are then expected to follow PBL syntax, i.e. collecting data, designing for solution and drawing conclusion, to answer problems.

\section{METHOD}

Research and Development (R \& D) method with ADDIE model, i.e. Analysis, Design, Development, Implementation and Evaluation is applied. Analysis relates to the analysis of content and context to find products needed to be developed. Design is a product design activity in accordance with what is needed. Development is the activity of making and testing products. Implementation is the activity of using a product, and evaluation is an activity to assess whether each step of the activity and product that has been made is in accordance with the specifications or not (Sugiyono, 2016: 38).

Research and development done in this study is to create a new product, i.e. an IPC thematic module based on PBL. Sugiyono (2016: 48) mentions the steps of research and development to create new products as follows: (1) Analysis of potential and problems; (2) Study of literature and information collection; (3) Product design; (4) Validation of design; (5) Revision of design; (6) Making product; (7) Limited testing; (8) Revision of product I; (9) Main field trials; (10) Product revisions II; (11) Operational field trials; (12) Product revisions III; and (13) Implementation.

Data obtained from the results of testing PBL-based module products are qualitative and quantitative data. Qualitative data are obtained from the results of product validation, the results of the main trial, the results of student questionnaire responses about PBL-based module and syntax implementation sheet in the operational field test. Quantitative data are obtained from the pretest and posttest results. The instruments used to collect data in this study are: (1) validation sheet; (2) questionnaire on student and teacher responses to PBL-based modules; (3) interview result; and (4) LO syntax implementation.

\section{DATA ANALYSIS AND FINDINGS}

The ADDIE model provides specific data as followed:

\section{a. Analysis}

An Interview with 30 primary teachers was conducted to gain data on learners' needs.

The following aspects appeared as things to design:

Table 1. Need Analysis

\begin{tabular}{ll}
\hline Variable & \multicolumn{1}{c}{ Need } \\
\hline a. & $\begin{array}{l}\text { Fulfilling the need of higher curiosity and enquiry in exploring } \\
\text { new material and knowledge. }\end{array}$ \\
b. & $\begin{array}{l}\text { Providing good media for students, so that they can solve } \\
\text { problems by themselves. }\end{array}$ \\
c. & $\begin{array}{l}\text { Fulfilling the need to have good critical thinking and problem } \\
\text { solving. By having these skills, students can identify, know the } \\
\text { reason and evaluate things to solve problems better. }\end{array}$ \\
d. $\begin{array}{l}\text { Promoting independence in solving problems. Teachers have to } \\
\text { lead students to analyse (think), give examples to find solution } \\
\text { (strategies), and find the best decision by understanding } \\
\text { consequences. }\end{array}$
\end{tabular}

Attitude

Students must be more independent and aware of their surroundings.

They need to get along with difficulties and handle them properly, to 
find idea to solve problems and to realize that they are members of social culture.

\begin{tabular}{cl}
\hline Local Wisdom & $\begin{array}{l}\text { Improving students' ability in promoting local wisdom, include } \\
\text { filtering values in real life situation }\end{array}$ \\
\hline Challenges & $\begin{array}{l}\text { Accommodating the speediness in learning, and preparing school } \\
\text { members to welcome global changes. }\end{array}$ \\
\hline
\end{tabular}

The data shown on Table 1 provides information on how students' thinking skills and ability to promote local wisdom are important aspects to analyze. Students need to be facilitated in order to be more independent and able to take the challenges to adapt and respond to changes. Completing the analysis, students' initial performance is then analyzed by seeing class documents, i.e. students' monthly and termly reports. The analysis is conducted to search for data on specific area researcher needs to focus on.

Table 2. Rubric on Students' Performance

\begin{tabular}{lc}
\hline \multicolumn{1}{c}{ Indicator } & $\begin{array}{c}\text { Average } \\
\text { Result }\end{array}$ \\
\hline $\begin{array}{l}\text { Ability to find out information from } \\
\text { newspapers, the Internet, other people, } \\
\text { stories and books }\end{array}$ & $100 \%$ \\
\hline $\begin{array}{l}\text { Ability to select and record information } \\
\text { relevant to the theme }\end{array}$ & $90,24 \%$ \\
\hline $\begin{array}{l}\text { Ability to place research information on a } \\
\text { chronological time frame }\end{array}$ & $90,85 \%$ \\
\hline $\begin{array}{l}\text { Ability to share ideas in a structured way } \\
\text { Ability to apply logical thinking in solving } \\
\text { problems }\end{array}$ & $89,37 \%$ \\
\hline \multicolumn{1}{c}{ Average } & $\mathbf{9 1 . 1 0 \%}$ \\
\hline
\end{tabular}

The rubric provides important data for researcher to identify that students are capable of exploring information through various sources. Students' abilities to share ideas in a structured way and to apply logical thinking in solving problems become main focus to develop. This study tries to correlate the need of developing logical thinking in solving problems.

The third aspect to analyze was on the school ways to facilitate students' need. Data on school facilities are important to be taken since it involves the use of technology to support students' activities. The following aspects are taken as major elements to follow up:

a. Correlating technologies to materials learnt in class, being effective learners

b. Facilitating students' higher thinking questions as a result of technology development

c. Leading students to use technology effectively, promoting reasoning

\section{b. Design and Development}

Before designing the prototype, researcher conducted a pretest to measure students' prior knowledge on current topic, i.e. local wisdom. Table 3 shows the result of pretest:

Table 3. Pretest Result 


\begin{tabular}{ccl}
\hline Class & Average Mark & \multicolumn{1}{c}{ Analysis } \\
\hline Control & 72 & $\begin{array}{l}80 \% \text { of total number of } \\
\text { students qualifies the } \\
\text { standard }\end{array}$ \\
\hline Experiment & 60.5 & $\begin{array}{l}\text { 38.09\% of total number } \\
\text { of students qualifies the } \\
\text { standard }\end{array}$ \\
\hline
\end{tabular}

The result shows that students' knowledge on local wisdom has not reached its good state. With only $38.09 \%$ of students in the experimental class qualifying the standard, researcher needed to follow up by introducing local wisdom to learning. Module that provides the need of developing students' problem solving skill by using local wisdom is designed and developed.

Facts and information related to the local city, i.e. Surakarta, is brought as a major issue to deliver in the learning. Researcher takes the importance of correlating the history of the city from earlier period of time to modern life. The history of Surakarta, significant people from Surakarta, its development in providing public transportation, the existence of traditional markets, its historical landmarks, local cultures and the city current situation are brought in the learning to trigger students' problem solving skill. Specific activity is set to fulfil students' need. Table 4 shows the forms of activity to nourish students' thinking skill:

Table 4. Module Design

\begin{tabular}{cl}
\hline Skills to Develop & \multicolumn{1}{c}{ Forms of Activity } \\
\hline $\begin{array}{c}\text { Problem } \\
\text { identification }\end{array}$ & $\begin{array}{l}\text { Activity } \mathbf{1} \\
\text { Students study the video material } \\
\text { attached to the module and identify } \\
\text { the problems presented in the } \\
\text { material. }\end{array}$ \\
\hline Information & $\begin{array}{l}\text { Activity 2, 5, 7, 10, 11, 12, 13, 14 } \\
\text { Students collect information from } \\
\text { various sources, i.e. the internet and } \\
\text { direct interviews. }\end{array}$ \\
\hline Ideas sharing and & $\begin{array}{l}\text { Activity } 3,8,9 \\
\text { Students express opinions in small } \\
\text { groups. } \\
\text { Activity } 4 \\
\text { Students plan problem solving steps }\end{array}$ \\
\hline Analysis & Activity 6 \\
& Students analyze and choose data. \\
\hline
\end{tabular}

Each activity set in the module provides specific approach to target the problem solving skills as determined in the preliminary research. The product validation was carried out by experts to measure the product eligibility before implementing it in learning. Table 5 shows the validation result scored by experts: 
Table 5. Product Validation

\begin{tabular}{cc}
\hline Expert & Score \\
\hline Instructional Media & $95.97 \%$ \\
\hline Material for content eligibility & $88.1 \%$ \\
\hline $\begin{array}{c}\text { Material for aspects of } \\
\text { presentation feasibility }\end{array}$ & $85.71 \%$ \\
\hline Language & $86.54 \%$ \\
\hline Average & $\mathbf{8 9 . 0 8 \%}$ \\
\hline
\end{tabular}

Reaching an average score of $89.08 \%$, gaining a level of good in its product eligibility, indicates that the IPC module is qualified to be implemented in the class. Feedbacks provided by experts are also taken as elements to develop the module. The importance of breaking down international curriculum to a more applicable solution considering the existence of local culture is an important aspect to follow up.

\section{c. Implementation}

Problem Based Learning in the IPC module provides data that students' mindset in digging information, developing ideas, planning, making decisions and conclusions undergo changes. This can be seen from the results of observations when students do exploring, thinking, planning, analyzing and synthesizing.

Table 6. Observation Result

\begin{tabular}{lc}
\hline \multicolumn{1}{c}{ Aspect } & Score \\
\hline Students are able to identify problems & $83.3 \%$ \\
\hline Students actively study IPC material & $90.5 \%$ \\
\hline $\begin{array}{l}\text { Students are able to dig up information through } \\
\text { literature studies and interviews }\end{array}$ & $91.7 \%$ \\
\hline Students show analytical skills & $83.3 \%$ \\
\hline Students show critical thinking & $82.1 \%$ \\
\hline Students show characters of independent learners & $88.1 \%$ \\
\hline Students are able to express opinions in a group & $82.1 \%$ \\
\hline Students are able to plan problem solving steps & $86.9 \%$ \\
\hline Students are able to draw conclusions & $75 \%$ \\
\hline Students are able to evaluate & $70.25 \%$ \\
\hline \multicolumn{2}{c}{ Average } \\
\hline
\end{tabular}

The result shows that students' competencies in being independent to study the materials, searching for information and planning have reached good qualities. However, the ability to express opinion, draw conclusion and evaluate become points of researcher's interest. Completing the analysis, posttest is conducted at the end of the learning to measure how effective the module is to develop students' thinking skill. 
Table 7. Posttest Result

\begin{tabular}{cclc}
\hline Class & Average Mark & \multicolumn{1}{c}{ Analysis } & Gain \\
\hline Control & 77 & $\begin{array}{l}\text { 85\% of total number of } \\
\text { students qualifies the } \\
\text { standard }\end{array}$ & 0.22 \\
\hline Experiment & 77.6 & $\begin{array}{l}\text { 95.24 \% of total number of } \\
\text { students qualifies the } \\
\text { standard }\end{array}$ & 0.43 \\
\hline
\end{tabular}

The posttest provides data on students' progress towards the use of local wisdom as aspect to learn in the module. The increasing number of students who qualify the standard, from $38.09 \%$ in the pretest to $95.24 \%$ in the posttest indicates that the use of module can promote better thinking skills. It is also supported by seeing the result gain, i.e. reaching a 'good' category at a level of 0.43 .

\section{d. Evaluation}

The use of module provides important data on students' behavior towards promoting problem solving skills. Students' abilities in making conclusion and evaluating have not reached equal levels of qualities as other problem solving aspects. The percentage of activity in the module that emphasizes the initial phases of problem solving syntax, i.e. problem identification, information gathering, developing ideas and planning can be the initial causes to have less progress in this area. Further research to promote these skills might be taken as feedbacks to produce a more effective module.

\section{RESULT, DISCUSSION, AND SUGGESTIONS}

The results of the learning evaluation showed $32.2 \%$ increase in class average and $95.24 \%$ of total number of students qualified the standard. Reaching result gain of 0.43 indicates that the module developed is good to be implemented in class activity. Students' skills in drawing conclusion and evaluating have not reached its maximum result. The observation result has clearly identified students' behaviour when given problems. The activities set in the module, taking the importance of promoting local wisdom to improve students' thinking skills, ignites students to be more independent in searching for potential solutions to solve problems.

The idea to promote local wisdom is aligned to the research conducted by Ardiansyah, Suharno, and Triyanto (2018). The implementation of cultural inheritance through learning in the City of Surakarta implemented by researchers was promoted in two main forms namely (1) through the programs of cultural inheritance habituation in everyday life in the learning that is by applying the use of Javanese language as a means of communication in the implementation of learning and singing regional songs, especially songs; and (2) integrate cultural heritage materials in subjects such as Javanese dance arts in Arts and Culture Subjects, or stand alone subject such as Javanese Subject, or as extracurricular activity in form of Karawitan Art. The use of Javanese language and cultural heritage materials become the focus of this research. While the IPC module as developed in this study refers to integrating international curriculum to national one.

Qomariyah (2019) states that the local-culture-based learning kit developed in the research is effective to improve students' analytical skills. Students will find it easier for them to also comprehend the lesson material by linking it with the environment and culture that exist around them. Local culture is integrated in the learning to develop students' analytical skill. It correlates to the result of research done by Sasmitatias (2018). Sasmitatias suggests using science learning kit designed by promoting local culture to support science learning activity. Attaching local culture in learning kit is aligned to current study to promote local wisdom in IPC module. Subject-based kit, i.e. science, as promoted by Sasmitatias has different approach to this study, 
Kristanto,A. Suharno \& Gunarhadi (2019). Promoting local wisdom in international primary curriculum aims to develop learners' problem solving skills. International Journal of Educational Research Review,4(3),439-447.

as current study emphasizes more on creating thematic-based module following the structures in the International Primary Curriculum.

Marshall \& Horton (2011) in Tajudin \& Chinnappan (2016) state that High Order Thinking Skills (HOTS), such as logical thinking, critical thinking and reasoning skills are basic skills in life, every day, regardless of the academic achievements of students at school. The research result is relevant to the purpose of this study. An understanding of the interrelationships between subjects is very important in developing curriculum integration. The difference is in the focus of the skills aspects that will be developed. Marshall and Horton developed HOTS in the realm of logical thinking, critical thinking and reasoning skills, while this research focused more on problem solving skills.

Wong (2012) states five main findings: (1) PBL teachers used different strategies to help students who were new to PBL to adapt to the new pedagogical practice, to facilitate group confrontation, and to help students become self-directed learners; (2) Choice, challenge, control and collaboration seem to have motivated students' learning in the PBL classrooms; (3) Disagreements about the problem situations stimulated task-related cognitive activity and resulted in academic progress; (4) Students' questions during collaboration facilitated learning by directing their' inquiry and expanding their thinking; and (5) Science test results show that the PBL group performed at least as well as the traditional learning group in knowledge acquisition, and that PBL helped the high achievers to retain information better than their peers in the traditional learning group. Wong sees the importance of developing students' thinking skills by implementing PBL in classrooms. It correlates to the purpose of this study to develop students' problem solving skill by implementing PBL.

This study puts more focus on promoting local wisdom to Grade 6 students of Primary Program Focus Independent School, Surakarta, Indonesia. The limitation on the use of curriculum, i.e. International Primary Curriculum, which allows teachers to adjust its learning objectives to local needs has led to a wider perspective towards identifying essential values to be integrated in the curriculum. Teachers' knowledge on local cultures is expected to strengthen the learning system in fulfilling both national and international curriculums as implemented in the module.

In future researchers, identifying students' prior knowledge on local wisdom is expected to increase researchers' ways in designing learning aid. Applying more technology-based learning aids shall also increase students' abilities in promoting how to be independent learners. Facilitating students to be more independent in learning, by providing effective learning aid will surely give more meaning to learning.

\section{REFERENCES}

Añonuevo, C.M., Ohsako, T. \& Mauch, W. (2001). Revisiting lifelong learning for the 21st century. Germany: UNESCO Institute for Education

Ardiansyah, R., Suharno, \& Triyanto. (2018). Inheritance national culture through learning in elementary school at disruptive era: Case study in Surakarta Indonesia. International Journal of Educational Research Review, $3(4), 48-53$

BNSP. (2006). Panduan Penyusunan Kurikulum Tingkat Satuan Pendidikan Jenjang Pendidikan Dasar dan Menengah. Jakarta: BNSP

Daryanto. (2013). Menyusun Modul: Bahan Ajar untuk Persiapan Guru dalam Mengajar. Yogyakarta: Penerbit Gava Media

Desmita. (2012). Psikologi Perkembangan Peserta Didik: Panduan bagi Orang Tua dan Guru dalam Memahami Psikologi Anak Usia SD, SMP dan SMA. Bandung: PT Remaja Rosdakarya

Fajarini, U. (2014). Peranan Kearifan Lokal dalam Pendidikan Karakter. Jakarta

Fieldwork Education. (2016). IPC Implementation File. London

Harefa, A. (2000). Menjadi Manusia Pembelajar (On Becoming a Learner). Jakarta: Kompas

Lumsdaine, E. \& Lumsdaine, M. (1995). Creative Problem Solving: Thinking Skills for Changing World. Singapore: McGraw-Hill Inc. 
Kristanto,A. Suharno \& Gunarhadi (2019). Promoting local wisdom in international primary curriculum aims to develop learners' problem solving skills. International Journal of Educational Research Review,4(3),439-447.

Mudjiman, H. (2011). Belajar Mandiri: Pembekalan dan Penerapan. Surakarta: UNS Press, LPP UNS

Qomariyah, S.N. (2019). Effect of problem based learning learning model to improve student learning outcomes. International Journal of Educational Research Review, 4(2), 217-222.

Raja, R.S. (1991). Education for the twenty-first century: Asia-Pacific perspective. Bangkok: UNESCO

Sasmitatias, F. \& Kuswanto, H. (2018). The development of science learning device based on Serukam local culture to improve students' analytical skill. International Journal of Educational Research Review, 3(3), 59-68.

Satyananda, I.M., Sanjaya, I.P.K., Dwikayana, K., \& Nitbani, S.H. (2013). Kearifan Lokal Suku Helong di Pulau Semau Kabupaten Kupang Nusa Tenggara Timur. Yogyakarta: Penerbit Ombak

Sedyawati, E. (2010). Budaya Indonesia: Kajian Arkeologi, Seni dan Sejarah. Jakarta: Rajawali Pers

Sugiyono. (2016). Metode Penelitian dan Pengembangan. Bandung: Alfabeta

Tajudin, N.M., \& Chinnappan, M. (2016). The link between higher order thinking skills, representation and concepts in enhancing TIMSS Tasks. International Journal of Instruction. 9(2), 199-214

UNESCO. (1996). Learning: The Treasure Within. France: UNESCO Publishing

UNESCO. (2012). The EFA Global Monitoring Report: Youth and Skills, Putting Education to Work. France: UNESCO Publishing

Wicaksono, A., \& Susanti, Y. (2016). Addressing local knowledge and local wisdom through writing using project based learning viewed from students' learning styles in cross culture understanding class: Proceeding. Semarang: UNNES

Wong, K.H. (2012). Implementation of problem-based learning in junior high school in junior secondary science curriculum. University of Hongkong 